\title{
Hydrogeophysical investigation in selected parts of Irepodun/Ifelodun local government area of Ekiti State, Southwestern Nigeria
}

\author{
Michael llesanmi Oladapo ${ }^{1 *}$ and Olayiwola Grace Ayeni ${ }^{2}$ \\ ${ }^{1}$ Department of Applied Geophysics, Federal University of Technology, Akure, Nigeria. \\ ${ }^{2}$ Department of Geophysics, Federal University Oye-Ekiti, Nigeria.
}

Accepted 16 July, 2013

\begin{abstract}
Hydrogeophysical studies have been undertaken at Irepodun/lfelodun local government area of Ekiti State, Nigeria. The area is underlain by the Basement Complex rocks. The study involved very low frequency electromagnetic (VLF-EM) and electrical resistivity methods. The results are presented as profiles, sections, curves, charts and maps. VLF-EM anomalies were evaluated using geoelectric soundings. Geoelectric sounding results enabled the determination of overburden thickness, transverse unit resistance, longitudinal unit conductance and coefficient of anisotropy $(\lambda)$. Overburden thickness zones of 45 to $55 \mathrm{~m}$ were classified as high, 15 to $\mathbf{4 5} \mathrm{m}$ as moderate and values less than 15 $\mathrm{m}$ as low. Afao, Obo, lyin, Araromi, Iketun and Igede are of moderate to high groundwater potential, while other towns are of low groundwater potential. Longitudinal unit conductance showed that the area is characterized by sequence of good, moderate and weak groundwater protective capacities. Computed $\lambda$ values revealed that the northern flank (Esure and Iropora) are underlain by charnockite of low $\lambda(1.0$ - 1.1) with other areas of high $\lambda(1.1-2.1)$ underlain by granite and migmatite gneiss. Groundwater development is feasible in Araromi, Afao, lyin, Obo, Iketun and Igede but marginally feasible in the other towns. Thus, groundwater potential of Irepodun/Ifelodun local government area is generally low.
\end{abstract}

Key words: Electromagnetic, geoelectric sounding, longitudinal unit conductance, coefficient of anisotropy, groundwater potential.

\section{INTRODUCTION}

The use of very low frequency electromagnetic (VLF-EM) and vertical electrical sounding (VES) for groundwater exploration is popular in the basement complex rocks terrains (Palacky et al., 1981; Smith, 1990). The electrical resistivity method has also been used extensively in groundwater investigation in the basement complex terrains (Barongo and Palacky, 1991; Olayinka and Olorunfemi, 1992; Ayolabi et al., 2004; Oladapo and Akintorinwa, 2007; Abiola et al., 2009; Oladapo et al.,
2009).

Irepodun/Ifelodun local government area which constitutes the study area is situated in Ekiti State and consists of villages and few towns. The inhabitants' major occupation is farming. For example, rice is produced in Igbemo-Ekiti and the primary need of sustaining the continued production of rice in the town is good quality water. Portable water to Igede, Iropora, Eyio, Esure,

Afao, Awo, Ilokun, Igbemo and Iworoko is from Ero 


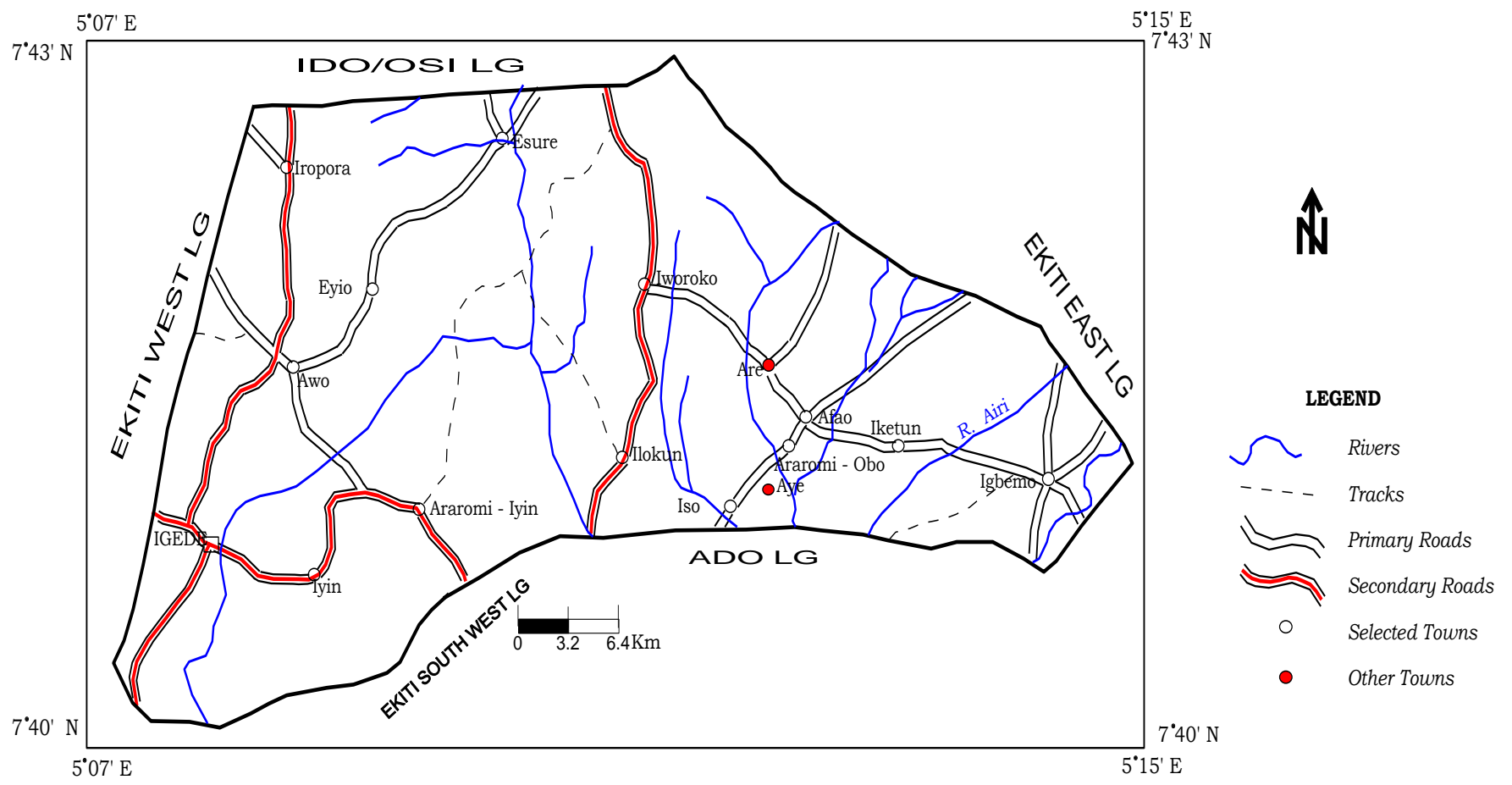

Figure 1. Location map of the study area.

Dam. The networks of pipes are not laid to serve many other communities in the study area (lyin, Araromi-lyin, Iso and Araromi Obo) due to the exorbitant cost of laying pipes to them.

Agricultural, industrial and domestic water needs of the areas not served by the pipe borne water can be best met with the development and adequate supplies of groundwater. Adoption of geophysical techniques which will assist in identifying the location of productive borehole sites and thus bringing to barest minimum the drilling of unproductive wells will be of great value.

Any elaborate groundwater development scheme in a typical basement setting requires a qualitative knowledge of hydrogeophysical parameters of the hydrogeologic units, that is, the superficial materials overlying the crystalline bedrock structures/relief (Omosuyi et al., 2003). In this study, VLF-EM and electrical resistivity methods have been utilized for a detailed hydrogeophysical investigation of the study area with the intention to determine geoelectric parameters (layer resistivity and thickness values) of the overburden materials overlying the bedrock and to derive second order geoelectric parameters.

\section{Physiography, geology and hydrogeology}

Irepodun/lfelodun local government area lies within latitudes $7^{\circ} 40^{\prime} \mathrm{N}$ and $7^{\circ} 43^{\prime} \mathrm{N}$ and longitudes $5^{\circ} 07^{\prime} \mathrm{E}$ and $5^{\circ} 15^{\prime} \mathrm{E}$ (Figure 1). Precambrian Basement Complex rocks underlie the study area (Figure 2). The major lithological units include the granites, migmatite gneiss and charnockite. The study area and location of the sounding stations are presented in Figure 3. A network of roads and footpaths make access to most parts of the area possible. The topography of the study area is gently undulating with the highest elevation of $649 \mathrm{~m}$ on the western flank of the area (Awo) and lowest elevation of $340 \mathrm{~m}$ on the eastern flank (Iketun).

\section{MATERIALS AND METHODS}

The VLF-EM method adopted for the field reconnaissance in this study utilizes plane wave field from military communication transmitters in the frequency range of 15 to $30 \mathrm{KHz}$. Radiations from these transmitters contain both electric and magnetic components, and travel in three modes; sky wave, space wave and ground wave. Of the electric and magnetic components, magnetic component is the one of interest, because beneath the ground surface, it carries bulk of the signal energy.

The direction and strength of the field generated by the transmitted radio signals are affected locally by electrically conductive structures on the surface or underground even when they are covered by thick overburden materials. A weak secondary field which is measured and analyzed normally builds up around the geological structure.

The equipment utilized for this study (ABEM-WADI) measures the field strength and phase displacement around the electrically conductive structures (presumably a fracture zone in a rock). A total of seventeen traverses were occupied with the VLF-EM profiling. The VLF-EM profiling measured the ratio of primary and secondary EM fields. The raw real component data of VLF-EM profiles were iterated using Karous-Hjelt filtering and computed Qfactor values.

Eight-nine VES locations were occupied, utilizing the 


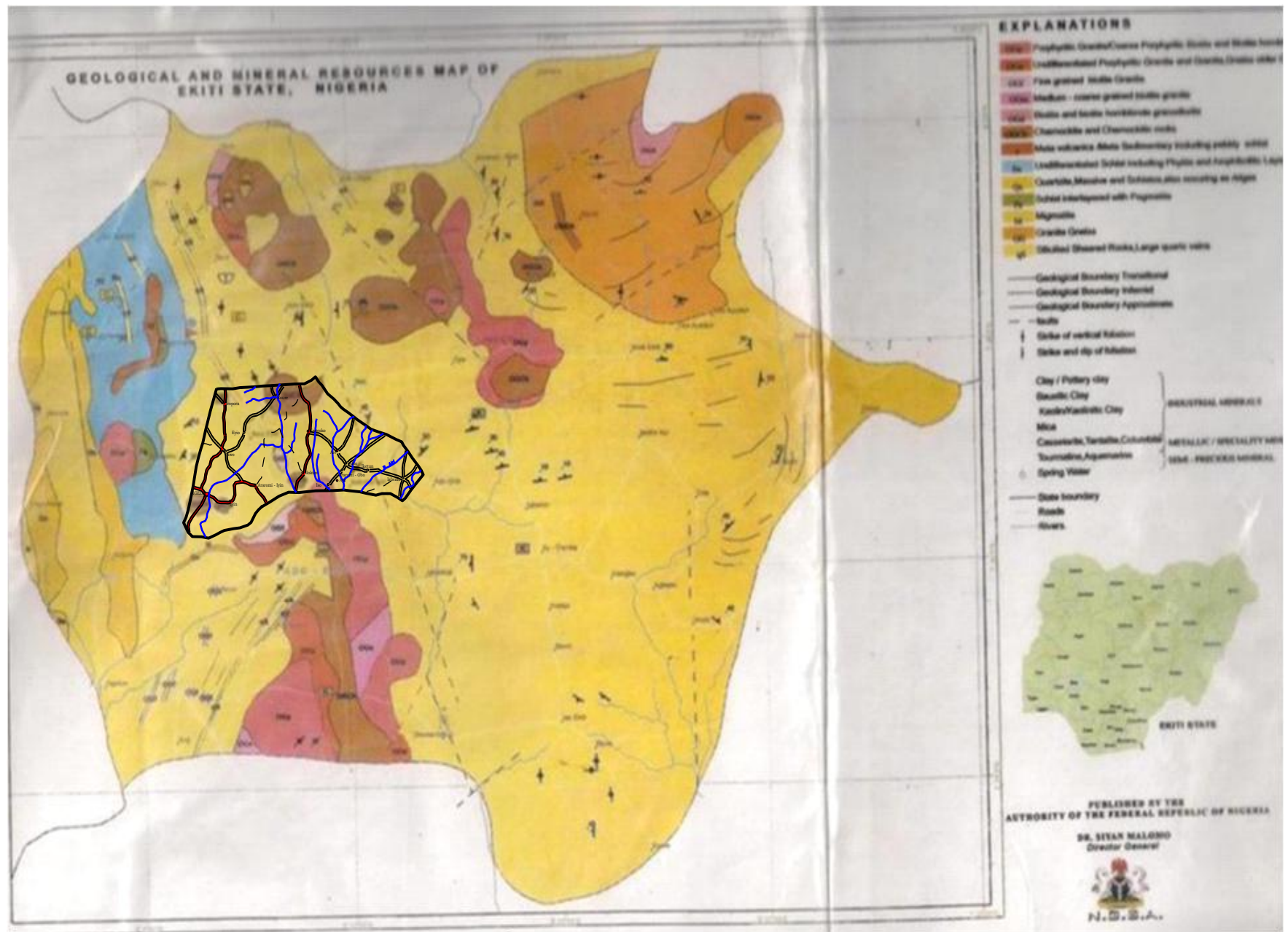

Figure 2. Generalized geological map of Ekiti State showing the study area.

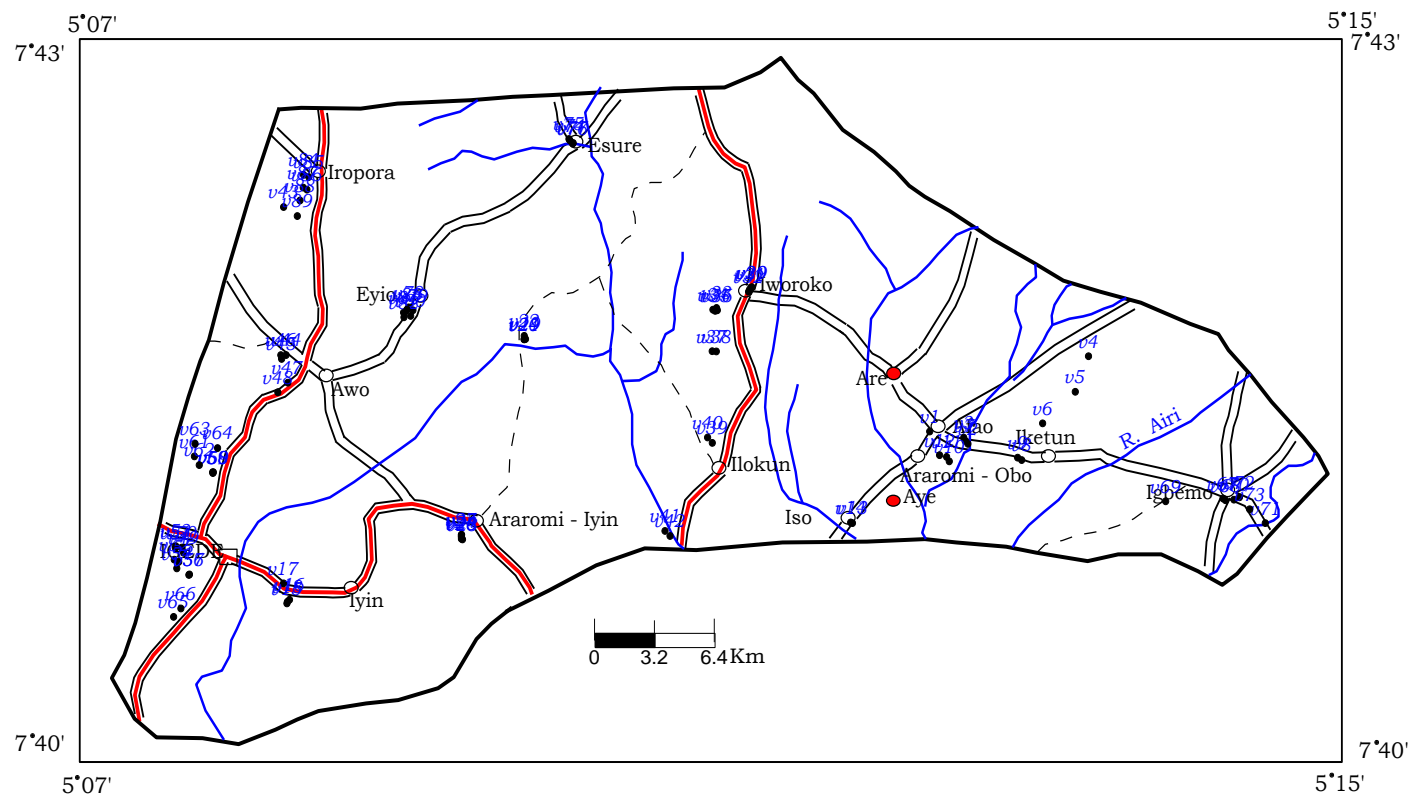

$\hat{N}$

LEGEND

$\curlyvee$ Rivers

-... Tracks

$\bigcup_{2}$ Primary Roads

Secondary Roads

- Selected Towns

- Other Towns

- $V \quad$ VES Locations

Figure 3. Map showing the VES locations in the area. 


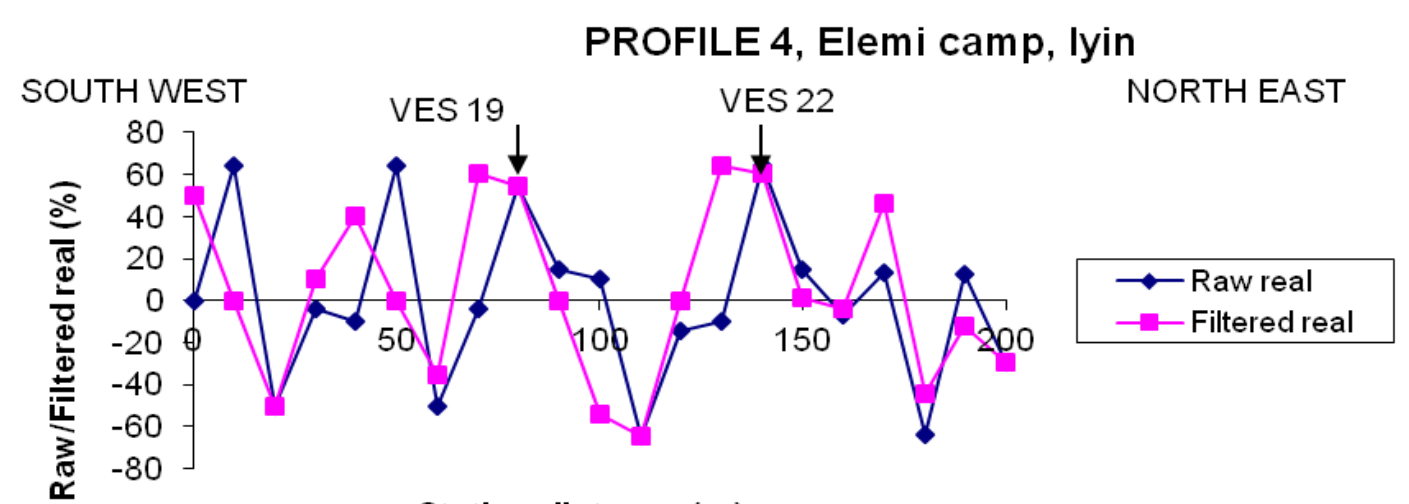

Station distance $(\mathrm{m})$

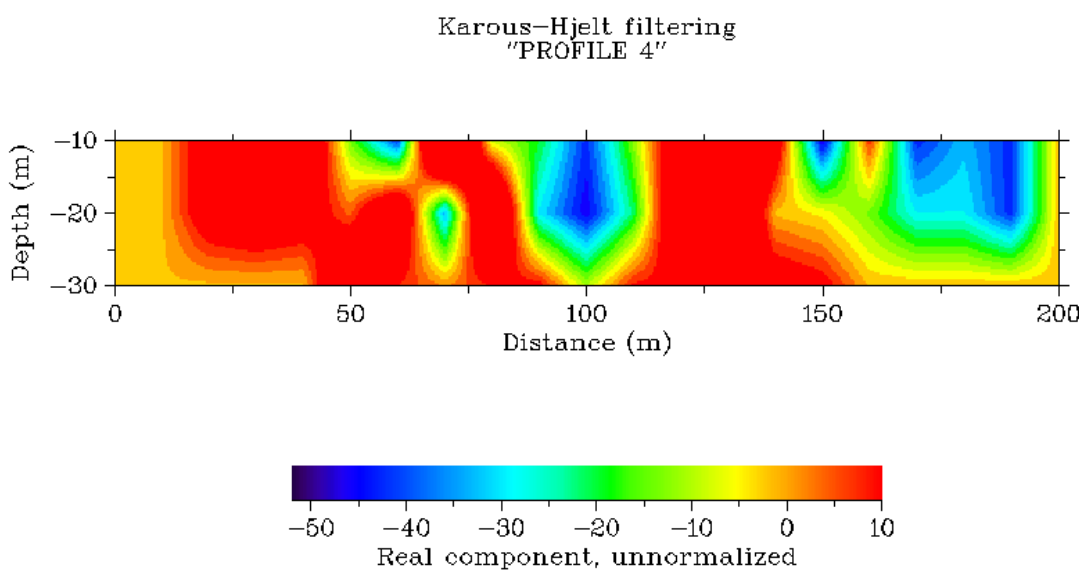

Figure 4. Typical VLF-EM profile and 2-D section obtained from the study area.

Schlumberger electrode configuration (Figure 3). Current electrode spacing $(A B / 2)$ was varied from 2 to $150 \mathrm{~m}$. The VES data were utilized for generating field curves that were interpreted using partial curve matching. RESIST version 1.0 (Vander, 1988) was utilized for the computer iteration. First order geoelectric parameters derived from the iteration were utilized in deriving second order geoelectric parameters or Dar-Zarrouk parameters (Maillet, 1947). The second order parameters of interest in the study are, longitudinal unit conductance $\left(\mathrm{S}_{\mathrm{i}}\right)$, transverse unit resistance $\left(\mathrm{T}_{\mathrm{i}}\right)$ and coefficient of anisotropy $(\lambda)$. The second order parameters are derived thus (Zohdy et al., 1974):

For $\mathrm{n}$ layer, the total longitudinal unit conductance

$$
\mathrm{S}=\sum_{\mathrm{i}=1}^{\mathrm{n}} \frac{\mathrm{h}_{\mathrm{i}}}{\rho_{\mathrm{i}}}
$$

The total transverse unit resistance:

$T=\sum_{i=1}^{n} h_{i} \rho_{i}$

And the coefficient of anisotropy is:

$\lambda=\sqrt{\frac{\rho_{t}}{\rho_{L}}}=\frac{\sqrt{T S}}{H}$

\section{RESULTS AND DISCUSSION}

VLF-EM profiling results are presented as profiles and 2D sections. Positive peak filtered amplitude values were interpreted as conductive zones, which is presumably occasioned by the presence of concealed geologic features like fractures, faults or weathered basement (Alvin et al., 1997). Thus, thirty-two (32) VES results were found to correlate with the features delineated using positive peak values on the VLF-EM profiles (Figure 4) The VES results are presented as sounding curves, chart, tables and maps. The sounding curve types obtained in the study area are $\mathrm{H}, \mathrm{A}, \mathrm{K}, \mathrm{KH}, \mathrm{HA}, \mathrm{HK}, \mathrm{HKH}$ and HKHK (Figure 5).

\section{Isopach map of the overburden}

The thickness of all the materials above the fresh bedrock at each of the VES locations and second order parameters obtained from the curve interpretation are utilized in generating the overburden thickness map (Figure 6). The overburden thickness map shows areas with relatively thick overburden ( $45 \mathrm{~m}$ and above), 

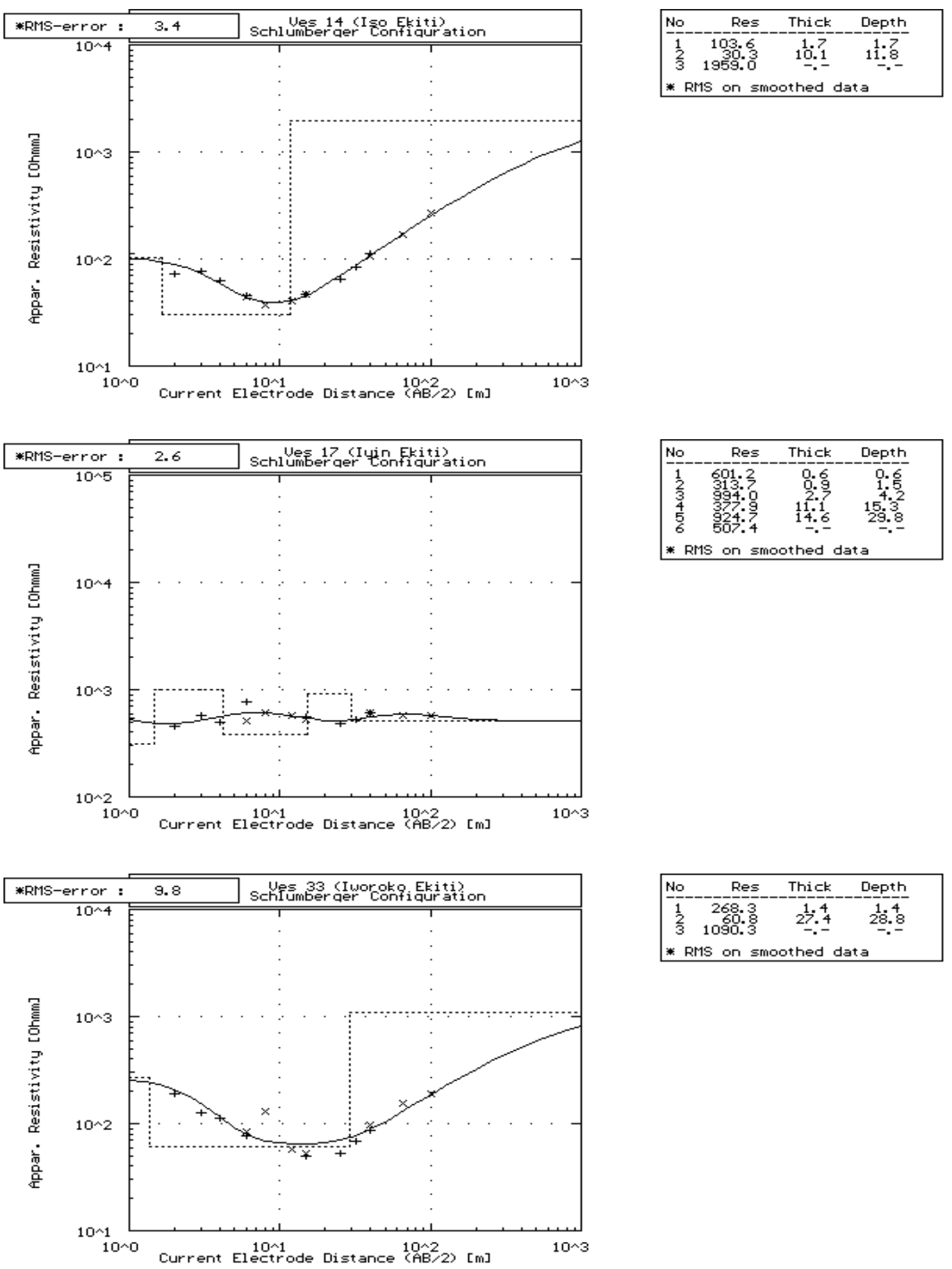

\begin{tabular}{|cccc|}
\hline No & Res & Thick & Depth \\
\hline 1 & 268.3 & 1.4 & 1.4 \\
2 & 60.8 & 27.4 & 28.8 \\
3 & $1090: 3$ &.-- &.-- \\
$*$ RMS on smoothed data \\
\hline
\end{tabular}

Figure 5. Typical sounding curves obtained from Irepodun/lfelodun area.

moderate overburden (between 15 and $45 \mathrm{~m}$ ) and relatively thin overburden cover (less than $15 \mathrm{~m}$ ). Studies in similar basement terrain (Bala and Ike, 2001; Omosuyi et al., 2003) have identified areas with thick overburden cover as high groundwater potential zones which include the following communities (Afao, Araromi Obo, lyin, Iketun, Araromi-lyin and Igede).

\section{Transverse resistance map}

The total transverse unit resistance $(T)$ is one of the Darzarrouk parameters and is defined as a measure of the summation of product of both the thickness and the resistivity of the geoelectric layers at each of the VES points (Maillet, 1947). Transverse resistance map 


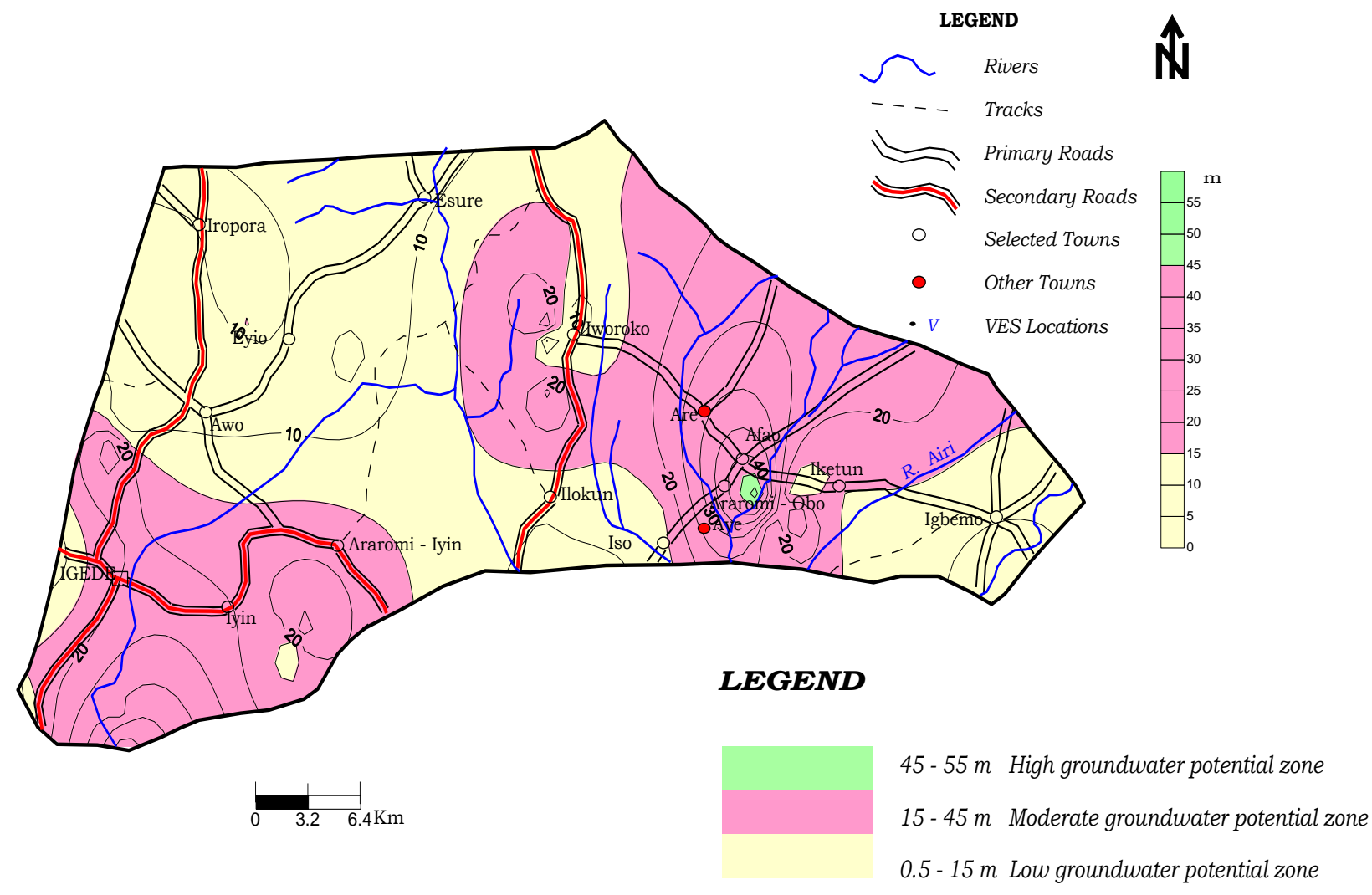

Figure 6. Overburden thickness map.

(Figure 7) shows area with relative high values (2000 $\Omega$ $\mathrm{m}$ and above) and low values (less than $2000 \Omega-\mathrm{m}$ ).

\section{Longitudinal conductance map}

The total longitudinal unit conductance values can be utilized in evaluating overburden protective capacity in an area (Oladapo et al., 2004).

The longitudinal unit conductance map (Figure 8) reflects the variation in conductivity within the study area and therefore presents the protective capacity distribution within the study area. The map shows that the overburden materials in Esure, Araromi-lyin, Iworoko, Afao, Iketun, Eyio, Araromi- Obo, Iso and Igbemo have moderate to good protective capacity ( 0.2 to 1.0 mhos). Iropora, Iyin, Igede, Awo and Ilokun with moderate overburden cover have weak protective capacity $(0.01$ to 0.2 mhos).

\section{Coefficient of anisotropy}

The coefficient of anisotropy $(\lambda)$ is a measure of the degree of inhomogeneity of a medium. It has been used to delineate lithological contacts in typical basement terrain (Olorunfemi and Okhue, 1992). Granite, migmatite gneiss and charnockite are the three major rock types identified within the study area. The migmatite gneiss and the granite are observed to be characterized by high values ranging from 1.1 to 2.1 (Figure 9), thus, suggesting that the weathering end products of the charnockite are less anisotropic than those of migmatite gneiss and granite as has been earlier observed by Oladapo et al. (2004). In this study, Esure and Iropora with low value of anisotropy (1.0 to 1.1$)$ are underlain by charnockite.

\section{Conclusion}

Hydrogeophysical investigations of Irepodun/lfelodun local government area of Ekiti State for the evaluation of groundwater potential as reported in this work has identified zones of high, moderate and low groundwater potentials. Afao, Araromi-Obo, lyin, Araromi-lyin, Iketun and Igede towns fall on moderate to high groundwater potential zones, while the remaining towns are situated within zones of low groundwater potential. Computed longitudinal unit conductance values showed that the area is characterized by subsurface sequence of good, moderate and weak groundwater protective capacities. Modified geologic map of the study area using $\lambda$ values revealed that the northern flanks of the area (Esure and 


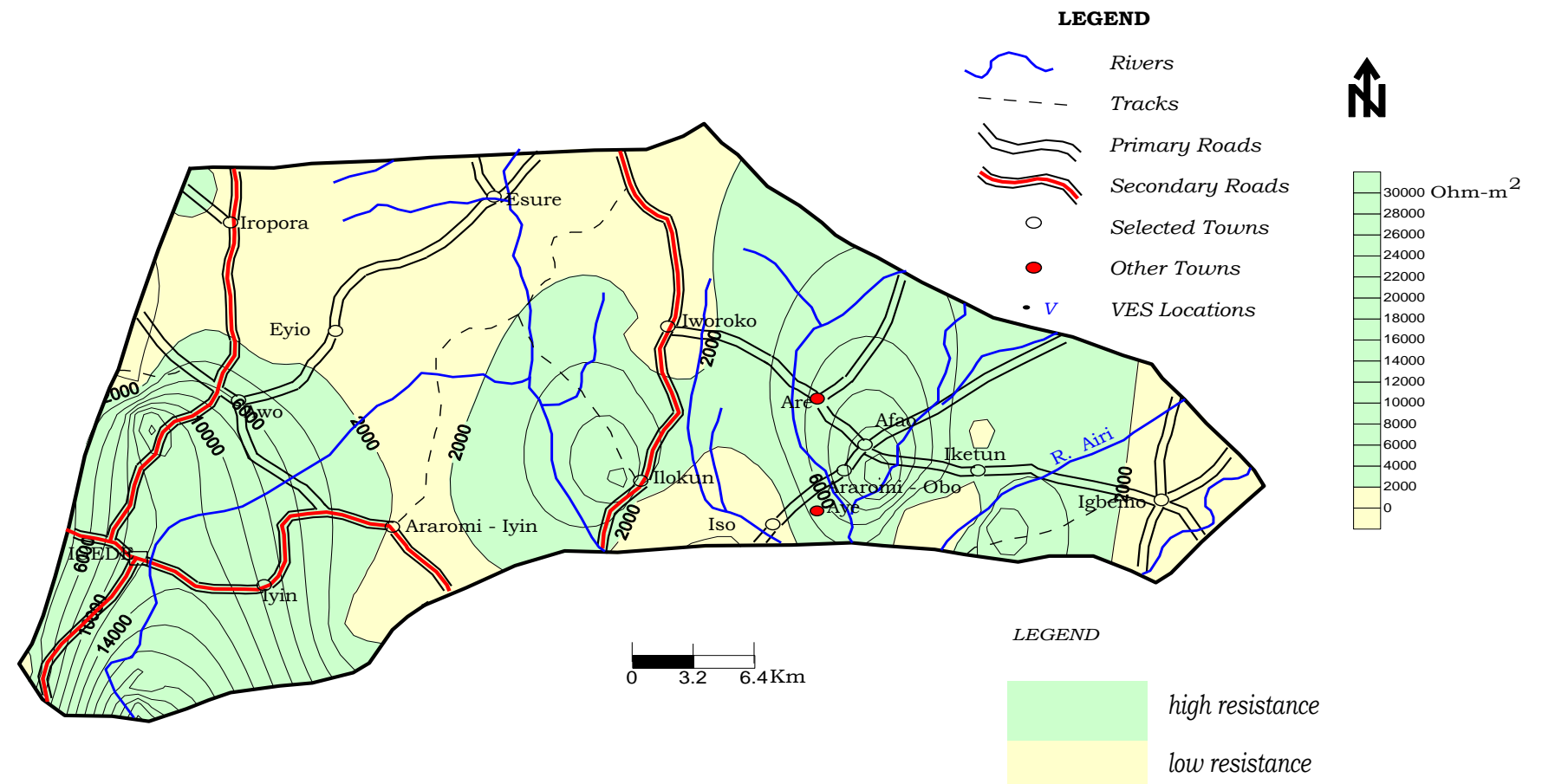

Figure 7. Transverse unit resistance map

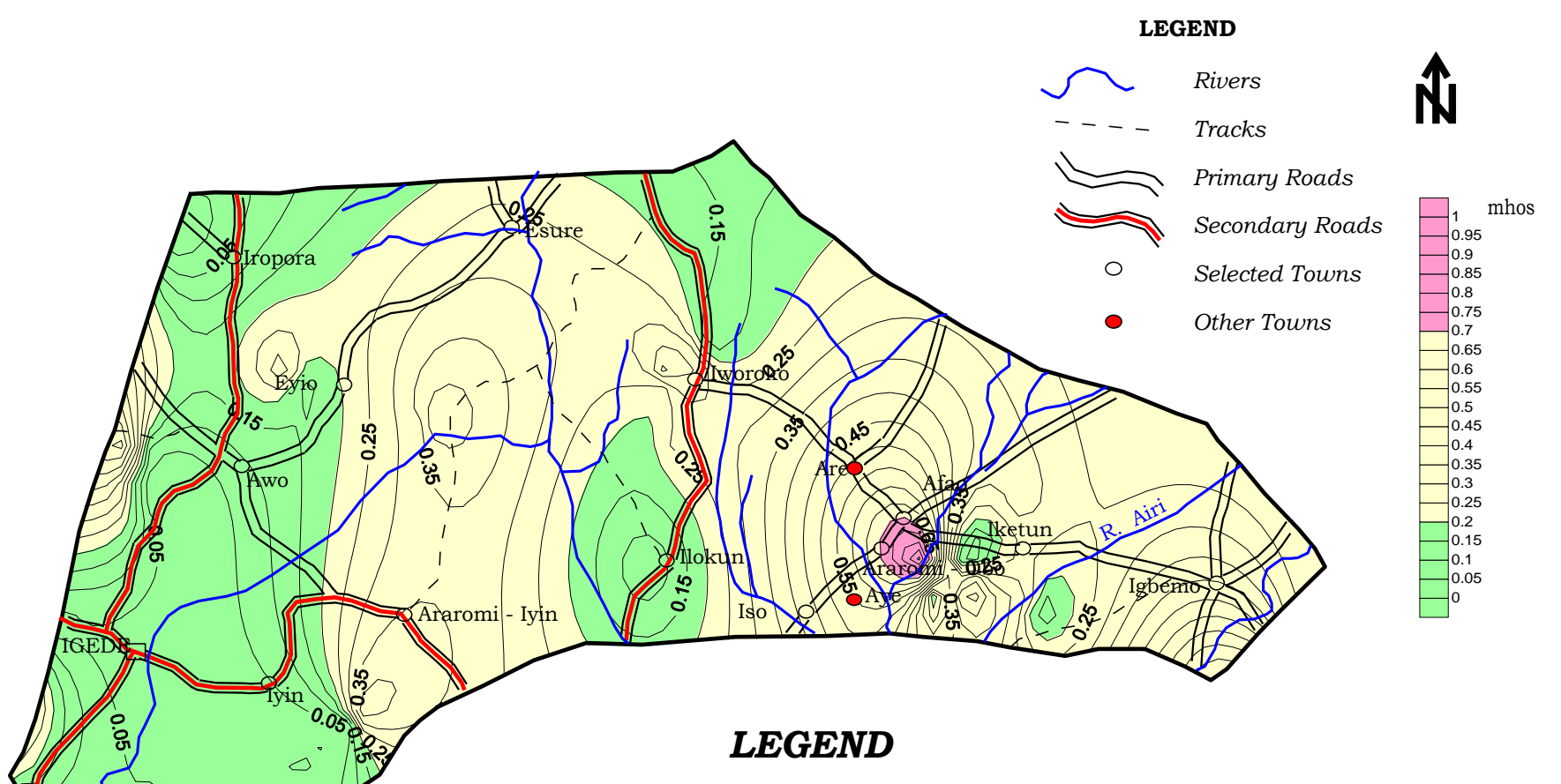

Good protective capacity layer

Moderate protective capacity layer

Weak protective capacity layer

Figure 8. Longitudinal conductance map. 


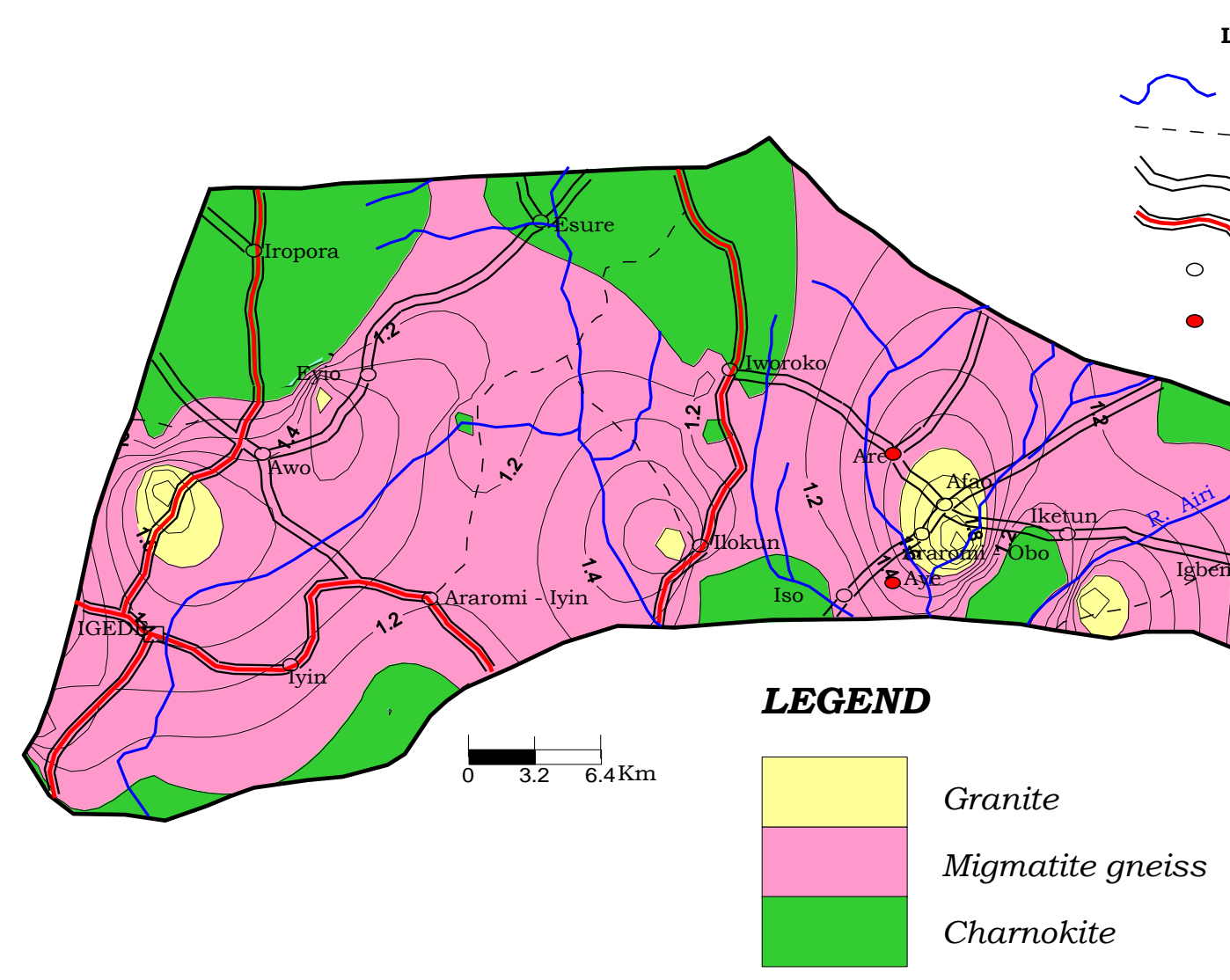

Figure 9. Modified geologic map of Irepodun/lfelodun local government area using coefficient of anisotropy.

Iropora) are underlain by charnockite of low $\lambda$ values (1.0 to 1.1$)$, while the remaining parts with high $\lambda$ (1.1 to 2.1$)$ are underlain by granite and migmatite gneiss. Groundwater development is fairly feasible in Araromi-lyin, Afao, lyin, Araromi-Obo, Iketun and Igede but marginally feasible in the other towns of the local government area. Thus, groundwater potential of Irepodun/Ifelodun local government area is generally low.

\section{REFERENCES}

Abiola O, Enikanselu PA, Oladapo MI (2009). Groundwater potential and aquifer protective capacity of overburden units in Ado-Ekiti, southwestern Nigeria. Int. J. Phys. Sci. 4(3):120-132.

Alvin KB, Kelly LP, Melissa AS (1997). Mapping groundwater contamination using dc resisting and VLF geophysical methods - A case study. Geophysics 62(1):80-86.

Ayolabi EA, Adedeji JK, Oladapo MI (2004). A geoelectric mapping of ljapo Akure southwest Nigeria and its hydrogeological implications. Global J. Pure. Appl. Sci. 10(3):441-446.

Bala AE, Ike EC (2001). The aquifer of the crystalline basement rocks in Gusau are, North-western Nigeria. J. Mining. Geol. 37(2):177-184.

Barongo JO, Palacky GJ (1991). Investigations of electrical properties of weathered layer in the Yala area, western Kenya, using resistivity soundings. Geophysics 56(1):133-138.
Maillet R (1947). The fundamental equations of electrical method of geophysical prospecting. Geophysics 12:529-556.

Oladapo MI, Adeoye-Oladapo OO, Mogaji KA (2009) Hydrogeophysical Study of the Groundwater Potential of Ilara-Mokin southwestern Nigeria. Global J. Pure. Appl. Sci. 15(2):195-204.

Oladapo MI, Mohammed MZ, Adeoye OO, Adetola BA (2004): Geoelectrical investigation of the Ondo State Housing corporation estate, ljapo Akure, southwestern Nigeria. J. Mining. Geol. 4(1):4148.

Olayinka Al, Olorunfemi MO (1992). Determination of geoelectrical characteristics in Okene area and implication for Borehole sitting. J. Mining Geol. 28(2):403-412.

Olorunfemi MO, Okhue ET (1992). Hydrogeologic and geologic significance of a geoelectric survey at lle-lfe, Nig. J. Min. Geol. 28:221-229.

Omosuyi GO, Ojo JS, Enikanselu PA (2003). Geophysical Investigation for Groundwater around Obanla-Obakekere in Akure area within the basement complex of Southwestern Nigeria. J. Mining. Geol. 39(2):109-116.

Palacky GJ, Ritsema IR, Dejong SJ (1981). Electromagnetic Prospecting for Groundwater in Precambrian Terrains in the Republic of Upper Volta. Geophysical Prospecting, pp. 932-955.

Vander VBPA (1988). RESIST version 1.0 M.Sc. Research Project, ITC., Delf Netherland.

Zohdy AAR, Eaton GP, Mabey DR, (1974). Application of Surface Geophysics to Ground-water investigations in: Techniques of Water Resources Investigations of the United States Geological Surveys United States Government printing Office, Washington. 